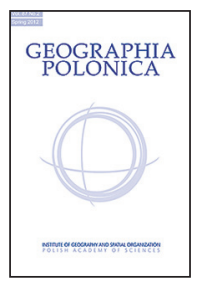 \\ INSTITUTE OF GEOGRAPHY AND SPATIAL ORGANIZATION \\ POLISH ACADEMY OF SCIENCES \\ www.igipz.pan.pl \\ www.geographiapolonica.pl
}

\title{
REVIVAL OF RURAL SETTLEMENTS IN KŁODZKO LAND
}

\section{Robert Szmytkie - Przemysław Tomczak}

\author{
Institute of Geography and Regional Development \\ University of Wrocław \\ pl. Uniwersytecki 1, 50-137 Wrocław: Poland \\ e-mails: robert.szmytkie@uwr.edu.pl • przemyslaw.tomczak@uwr.edu.pl
}

\begin{abstract}
During the post-war period the area of Kłodzko Land was subject to considerable depopulation processes which resulted in partial and total depopulation of outlying villages. For this reason the region is considered as problematic by many researchers, despite numerous attempts to revive it. In recent years, however, increasing variation in the trends of population change has been noticed and, besides the continually progressing depopulation, processes indicating the 'revival' of certain declining villages have emerged. This situation is a result of the influx of new residents, mainly from urban areas, who frequently run their own businesses and by doing so transform the functional character of particular villages.
\end{abstract}

\section{Key words}

rural areas - population change $\cdot$ depopulation - functional changes - Kłodzko Land

\section{Introduction}

During the post-war period the rural areas of the Sudety underwent significant processes of depopulation', however they were most visible in the area known as Kłodzko Land (Tomaszewski 1968; Chachaj 1978; Jerkiewicz et al. 1979; Salwicka 1978, 1983; Miszewska 1979, 1989; Zagożdżon 1990; Ciok 1994, 1995). Unfavourable changes in population in the region led to partial or total

1 However, the phenomenon had commenced as early as in the end of 19th century (see Eberhardt 1989). depopulation of many settlements and even entire rural areas, which, in turn, led to the decline of entire villages or parts of them (Chachaj 1978; Szmytkie 2008; Latocha 2013). Among the results of the aforementioned processes we can include changes in land use, which led to considerable lowering of the altitude of the agriculture-forest boundary or the dilapidation of development in abandoned villages (Zagożdżon 1990; Ciok 1995; Latocha 2007, 2009, 2011, 2012).

The settlements which underwent depopulation processes mainly comprised small, non-urbanised villages (up to 100 inhabitants) located in the upper parts of valleys above 
the so-called limit of the agricultural breakeven point, which, in Sudety, was established at 500-600 m.a.s.l. (Borkowski et al. 1966; Tomaszewski 1968; Zagożdżon 1990; Ciok 1995). The analysis of changes in the population of the villages in the region indicated that in the 1960s the majority of settlements (77.9\%) displayed a decrease or stagnation in their population (Jerkiewicz et al. 1979), and, between 1970 and 1978, a decrease in population was noted in $81.2 \%$ of villages (Miszewska 1979). In addition, the selective character of migration (mainly outflow of young people) caused a transformation of the demographic structures of villages, in particular producing an ageing of the population and lowering of the rate of natural increase (Zagożdżon 1990). In the 1990s the decline of rural settlements, together with the associated economic-ecological changes, were identified as one of the main problems of the Sudety region (Ciok 1991). Other mountainous regions of Central-East Europe underwent similar processes during the post-war period (compare with e.g. MacDonald et al. 2000; Wolski 2007; Soja 2008; Baumann et al. 2011; Drápela 2011; Mladenov \& Ilieva 2012; Novotná et al. 2013; Affek 2015).

However, over recent years a process of diversification has been noted in the population change and while the depopulation processes have remained, evidence of a 'revival' have also appeared in certain declining rural settlements. In the paper the notion of the 'revival of villages' is understood by the authors not only as an increase in population after a long period of depopulation, but also as a process of recovering (reactivating) of formerly lost functions (together with various expressions of socio-economic life) and even enriching (supplementing) the process with new forms of activity resulting directly from comprehensive improvements in standards.

The main aim of the paper is to present the issue of reviving villages, discussed via examples of rural areas in Kłodzko Land. During the post-war period, many settlements of this region transformed from abandoning villages (without perspectives for development) into reviving villages, which, in the current socioeconomic circumstances (through the use of dormant local potential) have found or are finding their path for development, or even a recipe for economic success. The phenomenon of the revival of villages in the Kłodzko Land area is presented in the context of the trends which have dominated population change in recent years. The analysis was conducted on the basis of data concerning the statistically defined settlements for the following years: 1988, 2002 and 2011 (census data) $)^{2}$, and, in the case of selected villages, also for 1933, 1950, 1960, 1970 and 1978. The analysis also used data on the size and structure of the rural accommodation services of the poviat, as it is tourism which has offered the opportunity to overcome 'socio-economic lethargy' to many settlements. In selected villages of Kłodzko Land (Bielice, Gajów, Jarków, Kąty Bystrzyckie, Lasówka, Lutynia, Nowy Gierałtów) free-form interviews with local leaders were also conducted in which the issue of demographic changes and the functioning of the local communities was raised.

\section{Kłodzko Land as a research area}

Kłodzko Land, a historical rather than a geographical notion, refers to an area on the border between the Central and Eastern Sudety Mountains, drained by the Nysa Kłodzka river and its tributaries, and centred around the broad Kłodzka Basin (Migoń 1996). The area's boundaries follow the administrative borders of the Kłodzko Poviat (district) and formerly these of the Kłodzko Province. Kłodzko land is distinguished from the rest of the Lower Silesia Voivodeship by its distinctive physiography. The area of the region (approx. $1700 \mathrm{~km}^{2}$ ), which, by its characteristic shape, resembles a quadrangle, cuts into the territory of the Czech Republic. As a geographical border region, it has often changed its national affiliation, and, as a result, became an area

${ }^{2}$ It is vital to emphasise the problem of the unregistered inflow and outflow of population caused by a lack of change of the residency address of inhabitants (see Śleszyński 2005). 
of conflict and intermingling of Polish, German and Czech culture. Despite the fact that after World War II Kłodzko Land was a place of total replacement of population, even today we can observe attachment to the region and a feeling of distinctiveness among its inhabitants. According to Czerwiński et al. (2003) deeply rooted historically conditioned economic transformations and continuous migration of the population resulted in the fact that the mountainous areas of the Kłodzko Land, unlike the Karpaty Mountains, lack an individual image, especially in the case of regional development and specific customs and traditions.

Until 1989 the Kłodzko region, like the entire Sudety region, was considered by the central government as a 'valuable German inheritance' and omitted in the allocation of the budget. The results of such a policy, visible in outdated technical infrastructure suffering from underinvestment, may negatively influence the future image of Kłodzko Land. Kłodzko Land is, above all, a region with distinctive environmental, landscape, climate, curative and cultural values. The attractiveness of the region is also confirmed by elements of geomorphological structure (unique rock formations), interesting floral groups, ruins of castles and its historic development. In order to protect the area of the highest environmental and landscape values it was decided to establish 11 nature and forest nature reserves, 2 landscape parks and 1 national park, this last being the highest category of environmental protection in Poland. Moreover, a trademark of Kłodzko Land is its network of health resorts which pride themselves on their high rank cultural events, as well as numerous religious sites.

According to "The development strategy of the Lower Silesia rural areas" (Strategia Rozwoju... 2001), Kłodzko Land, in a similar manner to the major part of the Sudety, was spatially assigned to so-called subregion III with industrial-touristic-recreational functions. Because of the low quality of agricultural

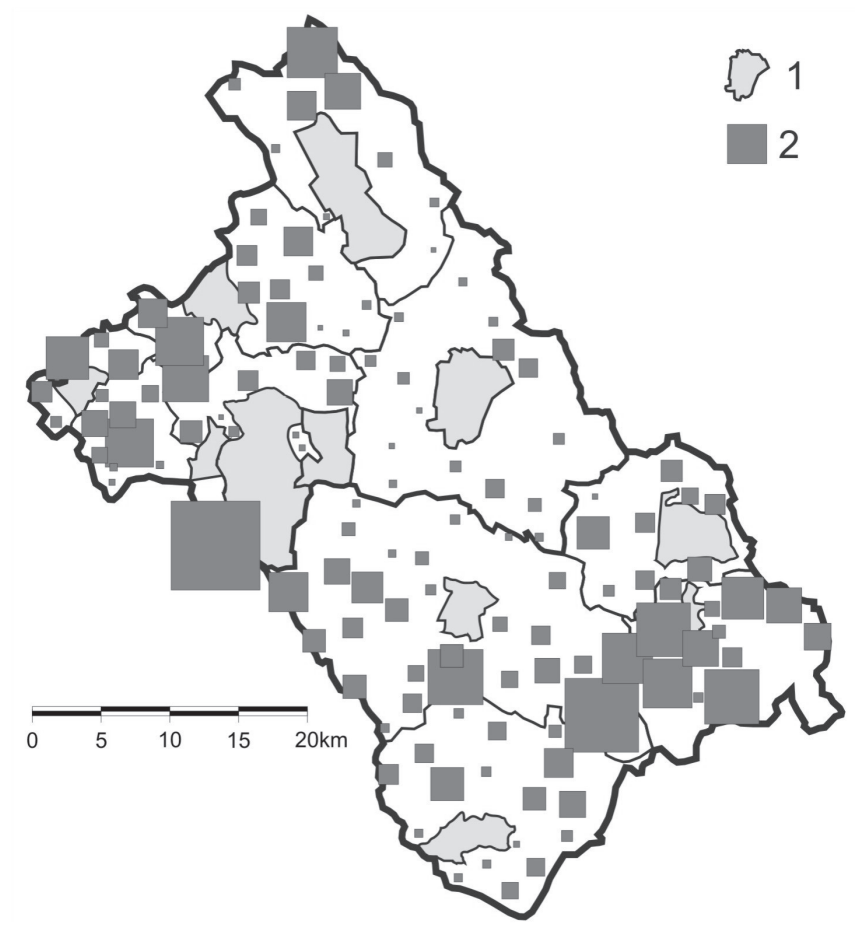

1 - urban areas; 2 - rural settlements with bedspaces (the size of the diagram is directly proportional to the number of bedspaces in the given settlement)

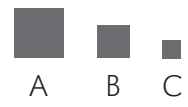

Bedspaces: A - 500; B - 250; C - 100 (continuous scale).

Figure 1. The rural tourist accommodation base in Kłodzko poviat in 2013 
production in the area (the proportion of the productive area in agricultural use in Kłodzko poviat is, on average, $58.3 \%$, while for the Lower Silesia Voivodeship it is $74.5 \%$, and for Poland $-66.6 \%$ ), as well as the high quality of its environment, recreational and tourist services could become the main source of income for the inhabitants of the region.

The importance of the tourist function in the rural areas of Kłodzko Land is reflected in the increase in rural tourist accommodation in the region (Potocki 2009). An inventory carried out in 2013 (Szmytkie 2015) confirmed that in rural settlements located in the Kłodzko poviat there are 596 accommodation sites (both collective and individual accommodation), with 15,080 bedspaces, of which 5,943 (39.4\%) are located in individual accommodation (i.e. agrotourism farms and room to let) facilities. The biggest accommodation base can be found in villages in the following gminas (communes): Bystrzyca Kłodzka (3,332 bedspaces) and Stronie Śląskie $(3,247$ bedspaces). The accommodation facilities are located in 128 villages of the poviat (Fig. 1). Among rural settlements of the Kłodzko poviat, the biggest accommodation base is in: Zieleniec (39 facilities and 1,492 bedspaces) and Międzygórze (39 facilities and 1,034 bedspaces), as well as Bolesławów, Stronie Śląskie Wieś, Długopole Zdrój and Sienna.

\section{Demographic characteristics of Kłodzko Land}

The current demographic situation in Kłodzko Land, like the course of demographic processes in the area, is mostly determined by the postwar period. After the end of WWII there was a total replacement of the population of the area. As a result, the settlement pattern had to be almost entirely reshaped. The ethnic profile of the region was transformed (Ciok 1994). Kłodzko Land, just like other recovered territories, was mostly populated by young people who rapidly started families. All those factors resulted in the creation of a very favourable population structure, with a big share of children and youth as well as people of working age, and with a relatively small share of older people.
Nevertheless, as the years passed by, what was initially an advantage for Kłodzko Land changed into a handicap. The most numerous tranche composed of young people, who settled on the area in the post-war period, in 1990s successively made a transition into the retirement age range (Górecka \& Tomczak 2008). Moreover, since 2012 there has been a great increase in the number of people of post-working age, which is connected with the transition of the population born in the 1950s in Kłodzko Land into the retirement age range. The demographic ageing process of this region is clearly visible in the value of the ageing index, which expresses the relationship between two economic age groups, the pre-working and post-working groups. In 2012 for every 100 people of pre-working age in Poland there were 97 (113 in towns, 77 in villages) people of post-working age, while in Kłodzko Land, there were as many as 120 people (137 in towns, 93 in villages). The most unfavourable value of the index was noted in the following gminas: Polanica Zdrój (172) and Duszniki Zdrój (151).

That is why it can be presumed that the value of the economic dependency ratio (the number of people in pre-working age and post-working age per 100 people in working age) could be relatively favourable, as in 2012 it amounted to 55 and was 5 points lower than the 2002 value (in Poland in those years it amounted to 61 and 57 respectively). However, a more thorough analysis of the ratio shows that the situation is only seemingly more favourable. The value of this ratio noted in 2012 was $55 \%$ generated by the post-working age group and $45 \%$ by the pre-working group. 10 years earlier this ratio was quite similar, however, with a bigger share of the pre-working group. In the case of the total value for Poland, the share of those two groups was almost equal.

Changes in the population of Kłodzko Land taking place between 2002 and 2012 were similar to those taking place in other parts of the country, but they were considerably more dynamic. Over the period analysed the population of Poland increased by $0.8 \%$, 
while the population of Kłodzko Land decreased by $2.5 \%$.

The population decreased in 10 out of the total of 14 gminas in the Kłodzko Poviat, while in 4 units there was an increase, including the rural gminas: Kłodzko and Lewin Kłodzki, the mixed urban/rural Szczytna and the urban Kudowa Zdrój. The last three are located along national road No. 8, while the rural gmina Kłodzko is a suburban area of the poviat town of Kłodzko. The process of depopulation was most intense in rural gminas. In the case of Nowa Ruda, the decrease in population amounted to $6.5 \%$ (Fig. 2).

The decrease in the number of inhabitants of Kłodzko Land noted between 2002 and 2012 was an effect of the outflow of population as part of internal and international migrations, but, most of all, natural population decline. In 2012 the rate of natural increase in Kłodzko Land amounted to $-3.6 \%$ (in urban areas $-4.0 \%$, in rural areas $-3.0 \%$ ). While in the same year in Poland it amounted to $0.0 \%$. During the decade analysed the rate of natural increase in Kłodzko Poviat had the highest value in $2009(-2.2 \%)$.

The low rate of natural increase in the Kłodzko Land mainly resulted from the low number of births. In 2012 the birth rate amounted to $8.3 \%$ o $(7.9 \%$ in urban areas, $8.9 \%$ in rural areas), while in Poland it was $10.0 \%$. Among the territorial units studied the lowest value was noted in Polanica Zdrój $(4.5 \%$ ). What is more, another factor which influenced the determination of the rate of natural increase was a high death rate $(11.9 \%)$, as compared with the national average of $10.0 \%$.

The future perspectives based on the results of the demographic prognosis until 2035 are also pessimistic. According to the Central Statistical Office (GUS), during the period 2011

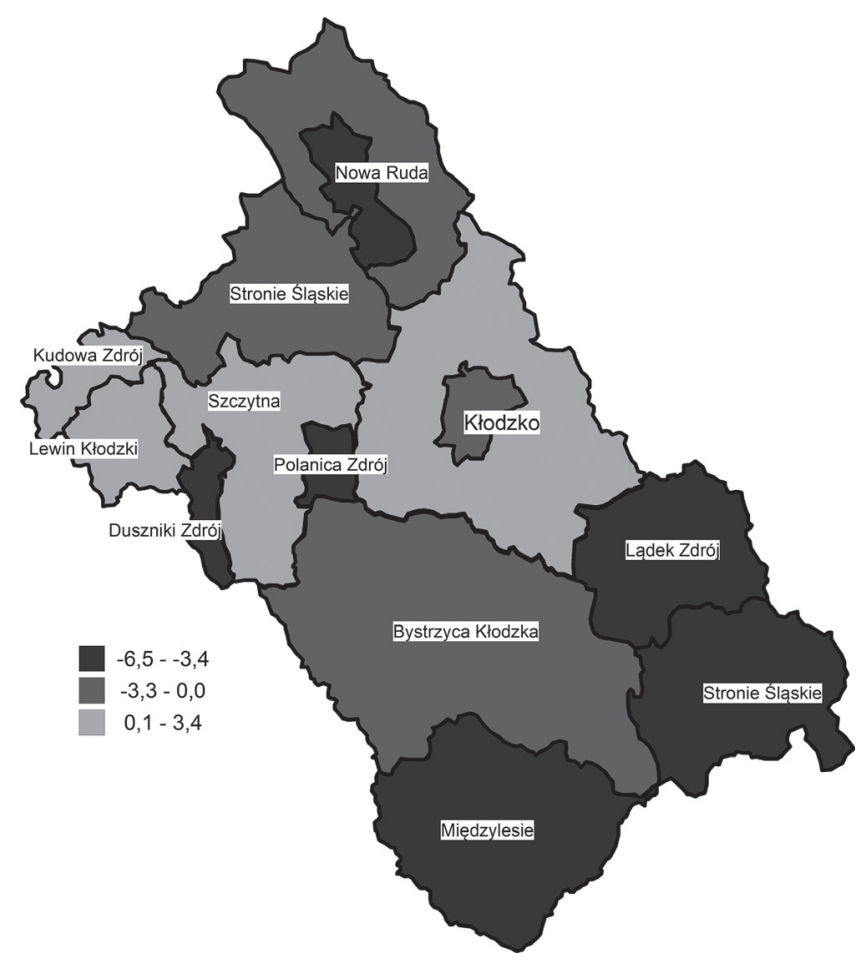

Figure 2. Population change in the gminas of Kłodzko Poviat in the years 2002-2012 (in \%)

Source: own analysis on the basis of data from Local Data Bank, Polish Central Statistical Office (LDB CSO) (the same applies to Figs. 3, 4 and 7). 
to 2035, the population of Kłodzko Poviat will decrease from 167,000 to 131,000 , so by $21 \%$ (for Poland and Lower Silesia the decrease in population will amount to $6.6 \%$ and $10.4 \%$ respectively) $)^{3}$. It is worth mentioning that during the immediately preceding period, from 1995 (the year when Kłodzko Poviat noted the highest population - 184,000) to 2011, the population of the area analysed had already declined by almost $10 \%$. If we take into account a decline in the population during the 1995-2011 period, and the unfavourable scenario that the prognosis concerning the population will prove to be true, during the next 40 years the population of Kłodzko Land will decrease by nearly 30\% (for Poland and Lower Silesia $7 \%$ and $12.5 \%$ respectively).

\section{Current trends in population change in rural settlements in Kłodzko Land}

An analysis of current population change in the area of Kłodzko land based on gminas points to an acceleration of depopulation processes, and rapid population ageing in Kłodzko Poviat (Fig. 2). A more detailed view of population processes taking place in the region is provided by an analysis of the number of inhabitants in comparison with statistically defined settlements (Figs. 3 and 4).

In the period 1988-2002 an increase in population was noted in only 31 out of 160 (19.4\%) rural settlements in Kłodzko Poviat (Fig. 3). In the period analysed the rural population of the poviat decreased by 5,642 inhabitants $(8.7 \%)$, which confirms the depopulation processes which have taken place during the entire post-war period. In that period a stable population situation was found in rural settlements located in the central and southern part of the Kłodzko Valley, especially neighbouring the main urban settlements of the region (Kłodzko, Bystrzyca Kłodzka). Definitely the least favourable population situation was

3 Because of an overestimation of the state of the population due to considerable foreign emigration, the decrease may be even larger (compare Śleszyński 2013). noted in small outlying rural settlements (under 100 inhabitants), where the highest decreases in the size of the population were noted, such as: Poniatów in Bystrzyca Kłodzka Gmina (by $66.7 \%$ ), Bieganów in Nowa Ruda Gmina (by $58.0 \%$ ), Potoczek in Międzylesie Gmina (by $54.9 \%$ ), Szczawina in Bystrzyca Kłodzka Gmina (by 54.0\%) or Niemojów in Międzylesie Gmina (by 50.0\%). The depopulation processes of settlements (including their decline) in that period were mainly found in the eastern (western mountainsides of Śnieżnik Massif) and western (the Bystrzyckie Mountains) outskirts of Bystrzyca Kłodzka and Międzylesie Gminas, as well as in Lewin Kłodzki and Stronie Ślaskie Gminas. Simultaneously, for the majority of depopulation processes analysed over that time, there were premises indicating a process of gradual revival of rural settlements still regarded as declining. Such a situation took place in, among other settlements, Wójtówka in Ladek Zdrój Gmina (by 26.2\%), Sienna in Stronie Śląskie Gmina (by 15.8\%), Topolice in Bystrzyca Kłodzka Gmina (by 8.7\%) or Studzienna in Szczytna Gmina (by 5.3\%).

In between 2002-2011 the trends in population change in the rural settlements of Kłodzko Poviat underwent considerable transformation. The rural population of the poviat increased by 652 people (1.1\%), and in 95 rural settlements of the poviat the number of inhabitants did not change or increased, including 49 villages with a change of at least $5.0 \%$ (Fig. 4). The processes of depopulation were still visible, nevertheless their scale significantly decreased (in only one settlement was a decline in population of at least $30 \%$ noted). When analysing the specificity and spatial variation of population change in Kłodzko Land between 2002 and 2011, it can be stated that the increase in the rural population was caused by two processes. Firstly, an increasingly clear process of suburbanisation, which manifests itself in an increase in the population in the villages surrounding Kłodzko (e.g. Boguszyn, Gołogłowy, Jaszkowa Dolna, Mikowice, Stary Wielisław) and located in the vicinity of a complex of urban settlements Polanica-Zdrój - Szczytna 


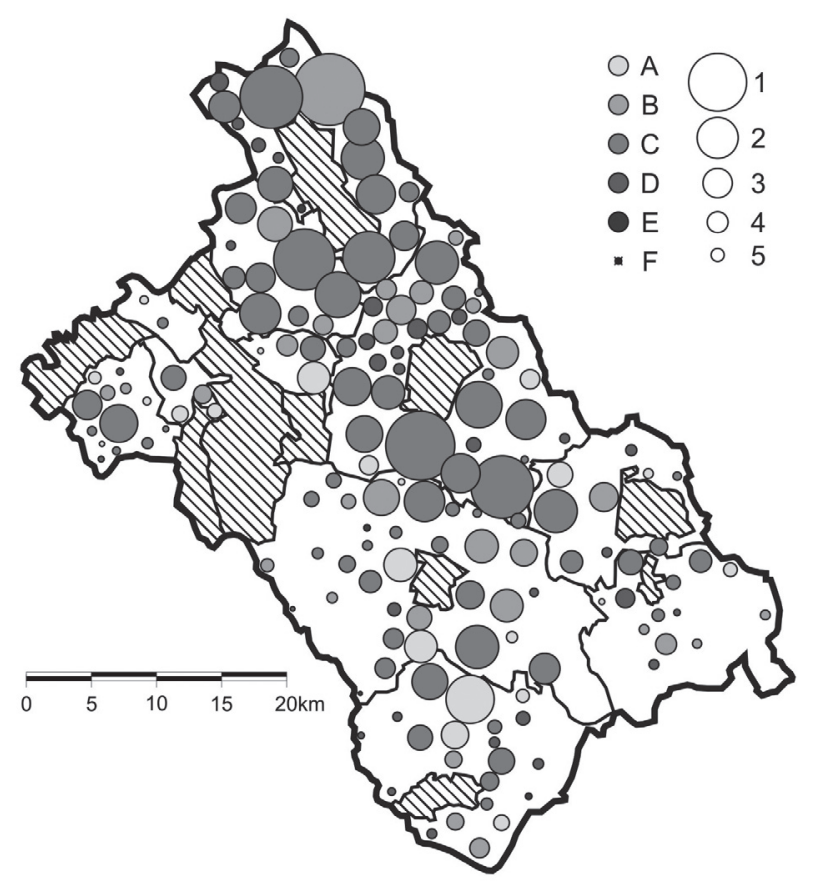

Population change

$(1988=100 \%)$ :

A - above 105\%;

B - 95-105\%;

C - 80-95\%;

D - 50-80\%;

E - below 50\%;

F - rural settlements depopulated during the period analysed.

Population in 2002:

1 - 2000 inhabitants;

2 - 1000 inhabitants;

3 - 500 inhabitants;

4 - 250 inhabitants;

5 - 100 inhabitants.

Figure 3. Population change in rural settlements of Kłodzko poviat in the years 1988-2002

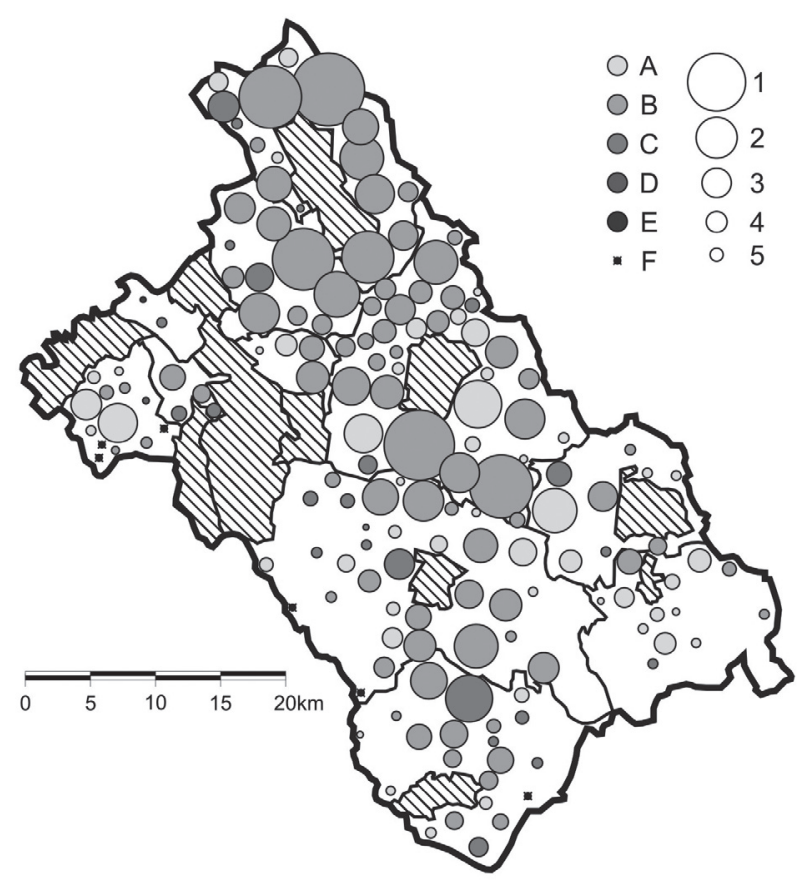

Population change

$(2002=100 \%)$ :

A - above 105\%;

B - 95-105\%;

C - 80-95\%;

D - 50-80\%;

E - below 50\%;

F - rural settlements depopulated during the period analysed.

Population in 2011:

1 - 2000 inhabitants;

2 - 1000 inhabitants;

3 - 500 inhabitants;

4 - 250 inhabitants;

5 - 100 inhabitants

(continuous scale).

Figure 4. Population changes in rural settlements of Kłodzko poviat in the years 2002-2011 
- Duszniki Zdrój - Kudowa Zdrój (e.g. Chocieszów, Jeleniów, Lewin Kłodzki, Wolany). The second process may be interpreted as a 'revival' of declining villages, which, during the post-war period, underwent considerable depopulation, often exceeding even $70 \%$ of the population in 1950. Among such settlements there are: Kamienna, Lasówka, Szklarka and Topolice in Bystrzyca Kłodzka Gmina, Lutynia and Wójtówka in Lądek Zdrój Gmina, Darnków, Jarków and Jerzykowice Wielkie in Lewin Kłodzki Gmina, Jaworek, Kamieńczyk, Lesica and Niemojów in Międzylesie Gmina, Kletno, Młynowiec, Nowa Morawa and Sienna in Stronie Ślaskie Gmina, as well as Studzienno in Szczytna Gmina.

\section{'Revival' of rural settlements in Kłodzko Land}

The process of decline and 'revival' of rural settlements in Klodzko Land is a quintessential example of the peculiarities of population change in the post-war period. They can be described according to the following scheme. There was a change in the political affiliation of Kłodzko Land (and the entire Silesia) in 1945 as a result of the changing of national borders which led to a replacement of the population. In place of a settled German population deported west, there was an inflow of Polish population mainly from the lowlands of Central Poland or, so-called, Eastern Borderlands.
It resulted in an interruption in the continuity of settlement, as well as a settlement of the Polish population in bigger towns located in the lower parts of valleys, where industrial plants were located; villages located in the upper parts were only partially settled (Fig. 5). The new population was also not used to farming in unfavourable mountainous conditions. The unstable political situation and difficulties in travelling in this borderland area inhibited tourist traffic. What is more, local traditions of craft, mining and herding also disappeared, which resulted in the disappearance of numerous hamlets and entire rural settlements located in the upper parts of valleys, especially those located above the so-called agricultural break-even point (Szmytkie 2008).

Change was only brought about by economic transformation and the related socioeconomic changes after 1989. These processes resulted in negative demographic tendencies in the rural areas of Kłodzko Land throughout the entire post-war period (Tomaszewski 1968; Jerkiewicz et al. 1979; Chachaj 1978; Salwicka 1978, 1983; Miszewska 1979, 1989; Zagożdżon 1990; Ciok 1994, 1995). The inhibition of the tendency of general decline of the rural population was not noted, nevertheless, since from the beginning of the 21st century there has been a steady increase in the number of new single family dwellings in the rural areas of Kłodzko Poviat (a significant share of which are so-called 'second homes'),

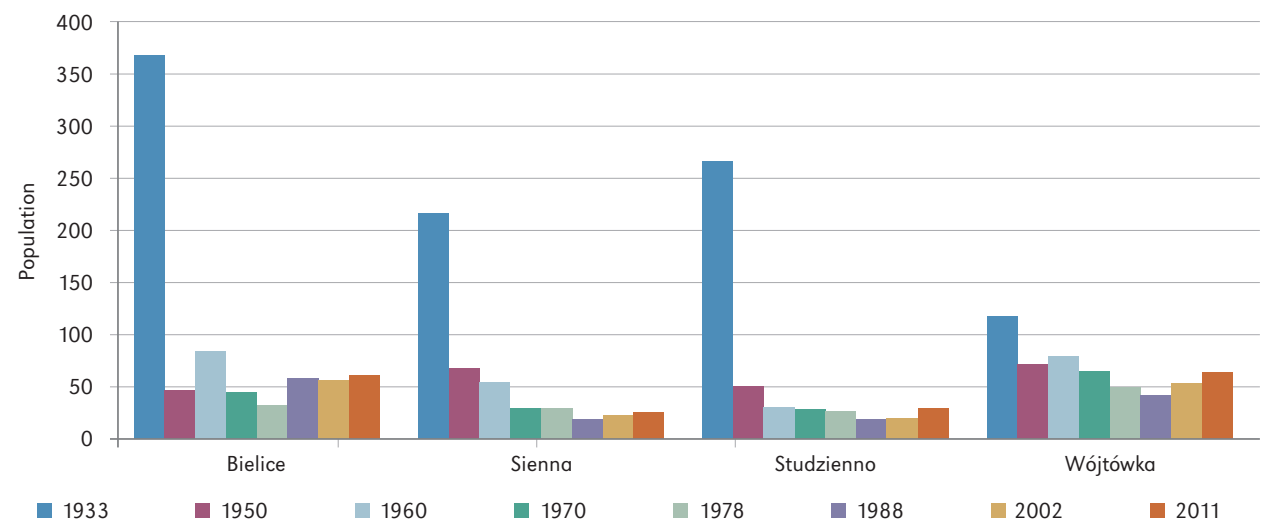

Figure 5. Changes in population in selected rural settlements in Kłodzko Land 


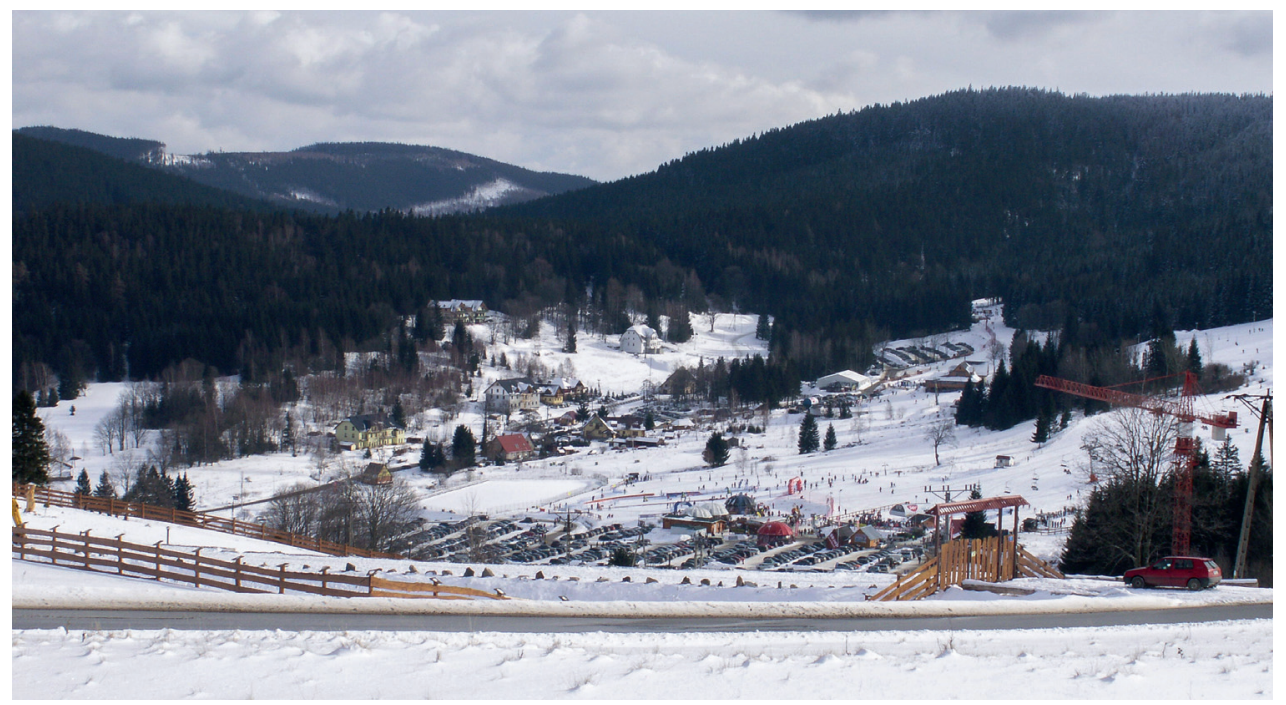

Figure 6. The Czarna Góra Ski Resort in Sienna (2013)

especially in the mountainous part of the poviat (Potocki 2000; Bryś \& Ojrzyńska 2010; Latocha 2010). This led to landscape changes in this part of the Sudety Mountains caused by intensive development, essentially restoring the tourist function to the region (Latocha 2013). In numerous villages there has been a large increase in accommodation services, often interfering with the initial spatial layout and physiognomy of rural settlements. And it is the reactivation of tourist functions which has inhibited the process of depopulation of mountainous rural settlements.
An increase in the population observed between 1988 and 2011 in several villages in Kłodzko Poviat previously undergoing a process of depopulation does not constitute a significant quantitative change (an increase amounting to from several to a dozen or so per cent in the case of small villages, usually with a population of up to 100 inhabitants), however it constitutes a qualitative change (Fig. 7), which is why this process cannot be marginalised. The main factor in the population changes in those rural settlements is the inflow of population from urban settlements,

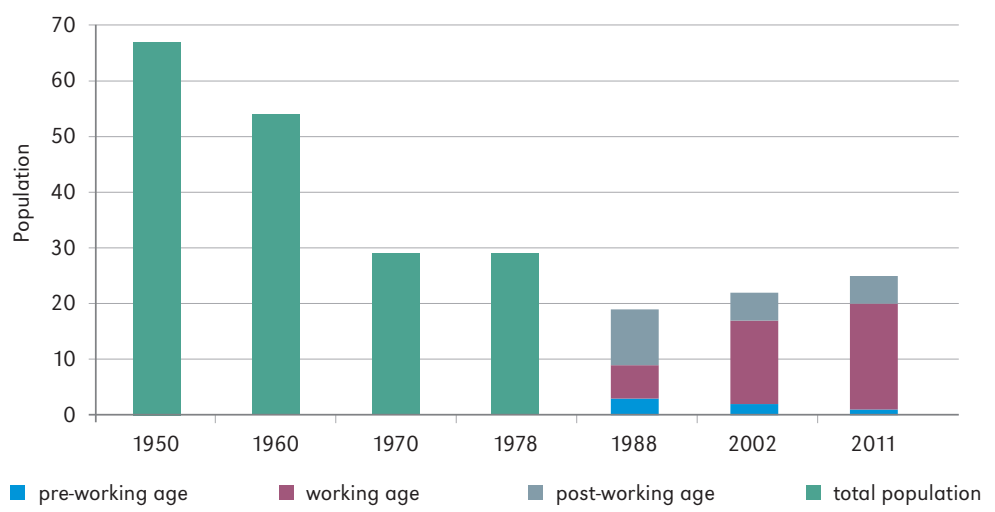

Figure 7. Population of Sienna (with Janowa Góra) in the post-war period 
especially large ones, often at a considerable distance from Kłodzko Land (Wrocław, Poznań, Warsaw) ${ }^{4}$, which leads to significant rejuvenation of the age structure and changes in the education structure of the inhabitants of rural settlements. New inhabitants also contribute to functional changes and revive the economy of villages, undertaking and developing business activities (especially in the realm of tourism and agrotourism) and organising various initiatives which might be identified as creative activities (compare Namyślak 2013; PijetMigoń \& Migoń 2014), e.g. Bielice University (Stronie Śląkie Gmina) or the Japanese Garden in Jarków (Lewin Kłodzki Gmina). Other subjects of functional change are areas of already depopulated rural settlements, where new investments are located (Latocha 2013).

A perfect example of a 'reviving' rural settlement is Sienna in Stronie Ślaskie Gmina. Throughout the entire post-war period Sienna was depopulating, declining to 19 inhabitants in 1988. In the 1970s the authorities attempted to create a ski resort there as a part of the 'Second Zakopane' project, however those plans were not realised (Salwicka 1978). In 1996 a ski centre Czarna Góra (Fig. 6) was opened in the area of the settlement, which made a considerable contribution to the revival of tourism in the entire Śnieżnik Massif. As a result, there was a rapid development of tourist infrastructure in Sienna and its neighbouring villages (in Sienna alone in 2013 there were 485 bedspaces). In the settlement there was also a slight increase in population (Fig. 7) caused by migration inflow, which resulted in a considerable rejuvenation of the population structure and a transformation of the education structure of the inhabitants of the settlement.

Another village located in Stronie Ślaskie Gmina is the settlement of Bielice. After WWII the settlement was systematically depopulated. In 1978 there were only 9 inhabited households in Bielice. The decline of the

\footnotetext{
${ }^{4}$ As indicated by the free-form interviews conducted among the inhabitants of selected villages in Kłodzko Land.
}

village was only stopped by the two forestry enterprises which operated within its boundaries. In 1970s both Wrocław intelligentsia and people affiliated with the Baptist church began to settle in Bielice. It was also the time of the building of 'Chatka Cyborga' - a facility for students of the Cybernetics Department of Wrocław University of Technology and Sciences. Thanks to all these changes, the settlement became a well-known and often visited tourist site. In between 1981-89 it was also a meeting place of the Polish and Czechoslovakian anti-communist movements. Since June 2002, Majowie Guesthouse has been the location of the so-called 'Bielice University', which organises meetings with interesting people, such as scientists, researchers, travellers and journalists. In addition, thanks to cooperation with Chata Paprsek in the Rychlebské Mountains (Czech Republic), Bielice is also a place known for cross-country skiing.

The rural settlement of Lasówka (Bystrzyca Kłodzka Gmina) is located on the other side of Kłodzko Land, in the Dzika Orlica Valley. The village was established in the 17th century in the vicinity of a glass factory, while in the 19th century a match factory was opened there. During the interwar period, the settlement was also a popular holiday resort. After WWII the industry disappeared in that region, and, because of the location of the village next to the border, Lasówka ceased to be a tourist venue. As a result of the changes mentioned above, the settlement started to depopulate. At the end of 1990s, the village started to be settled by a population mainly originating from Wrocław and other big urban settlements located in central Poland. New buildings serving the function of 'second homes' began to appear in the village. However, a considerable number of the new inhabitants settled there permanently which resulted in the reactivation of the local community (renovation of the local church (Fig. 8), organisation of Lasówka Days and numerous recreational and sports events; a majority of the buildings serve as agritourist farms). Among the factors which contributed to the revival of the 


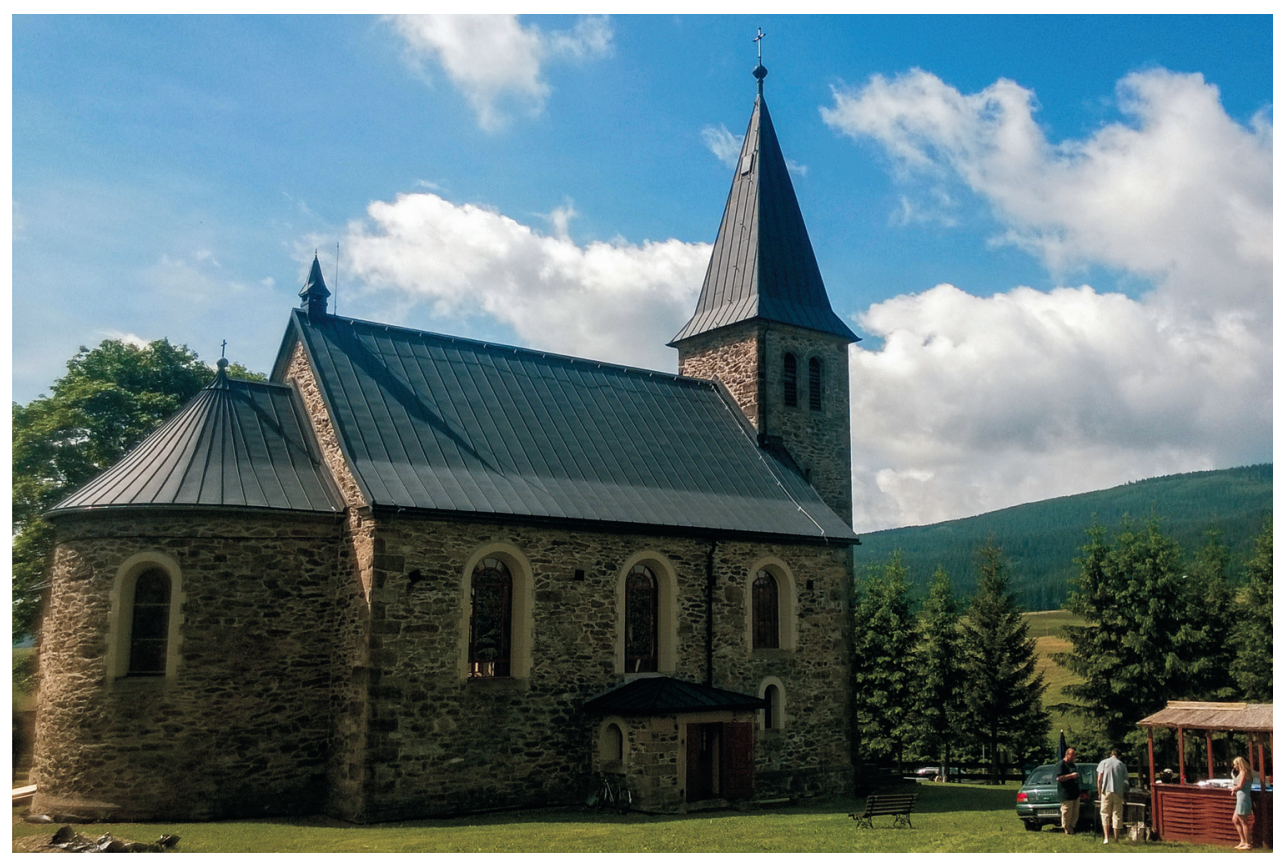

Figure 8. Saint Anthony's Church in Lasówka

settlement, one can list its favourable location, as well as the proximity of the ski resort in Zieleniec.

One of the manifestations of the qualitative changes currently taking place in the local communities of the depopulating rural settlements of Kłodzko Land is the functioning of websites devoted to particular settlements (Tab. 1), as well as to local associations. Usually the activities cited are run by so-called 'local leaders', who play an important role in the reactivation of local communities. Usually they are individuals with higher education, who arrived in the village from a big urban settlement (mostly from Wrocław) a few or a dozen years before. These people, inspired by the beauty of the landscape, calmness and lifestyle different from that of a big city, found their dream dwelling places in these depopulating villages.

Table 1. Websites of selected reviving villages in Kłodzko Land

\begin{tabular}{|l|l|c|l|}
\hline \multicolumn{1}{|c|}{ Village } & \multicolumn{1}{|c|}{ Commune (gmina) } & Population in 2011 & \multicolumn{1}{c|}{ Website [25 August 2016] } \\
\hline Bielice & Stronie Ślaskie & 61 & $\begin{array}{l}\text { www.bielice.info.pl } \\
\text { www.bielice.pl }\end{array}$ \\
Kletno & Stronie Śląkie & 46 & www.kletno.info.pl \\
Lasówka & Bystrzyca Kłodzka & 108 & www.lasowka.info \\
Lutynia & Lqadek-Zdrój & 51 & www.lutynia.ladeckiewioski.pl \\
Niemojów & Międzylesie & 26 & www.niemojow.info \\
Taszów & Lewin Kłodzki & 12 & www.taszow.pl \\
\hline
\end{tabular}




\section{Conclusion}

Based on the analyses conducted concerning current trends in population change in rural areas in Kłodzko Land, the following conclusions can be drawn:

- The population processes that have taken place in the rural settlements of Kłodzko Land are of a complex nature, therefore they should not be considered as a simple system. Besides the constant depopulation dominating in numerous settlements and ageing processes, new phenomena are starting to emerge, such as: suburbanisation in the vicinity of Kłodzko or the inflow of population from big urban settlements and the revival of villages considered until now as declining.

- The revival of villages mainly located on the Śnieżnik Massif and in the Bystrzyca Mountains is a process taking place on a small scale (resulting in a minor growth of population) as far as the quantitative aspect is concerned. Nevertheless, what is important is its qualitative aspect. As a result of the inflow of new inhabitants, in numerous villages there has been an almost total replacement of the population, which has led to a considerable lowering of the age structure and a transformation of the structure of education. New inhabitants contribute to the reactivation of local communities by undertaking and developing both economic and social activities.

- The rural settlements of Kłodzko Land are undergoing intensive development and are regaining their tourist function. The tourist function constitutes a solid ground for the development of this area however it will definitely not solve all its socio-economic problems. That is why, depending on the type of gmina, it should be adequately supplemented by other forms of activity, such as industry, which was the mainstay of the functioning of the Sudety villages until the end of the 20th century.

Here is it important to consider the causes of the phenomenon of the revival of rural settlements in mountainous regions. In the opinion of the authors these are:

- A growing awareness of the possibilities of the unused potential of these regions. Today such regions are not considered simply as places of hard farm work in difficult mountainous conditions, or as an idyllic tranquil retreat for artists looking for an escape from the hustle and bustle of a city, but also as a source of potential income.

- The increasing economic activity of the inhabitants of reviving villages. In previous years such activity concentrated mainly on traditional agricultural production, however, for a dozen or so years now, it is in many cases supported by other types of activity (e.g. agricultural activity). By doing so, the inhabitants are able to use additional living space in their houses and utility buildings.

- Increasing dynamics related to the emergence of new entities outside the agricultural realm which is often related to outside capital. This economic stimulus, often coming from urban areas, is frequently observed and copied by the local population. Such copying of good practice (ideas for one's own business) reassures the inhabitants as to the local potential of the area (e.g. as to the above average, often unique environmental value) and, thereby provides even stronger stimulation of economic activity of the settlements examined.

- The increasing mobility of the inhabitants. The declining villages have always struggled with accessibility to transportation (it was one of the main reasons for their decline). Currently, despite continuous exclusion with regard to transportation (in the case of public transportation), it does not seem to constitute such a serious hindrance, as the majority of inhabitants are able to afford their own means of transportation.

- An increasing significance of modern means of communication and the popularisation of e-work. As a result of the developments mentioned above, distances seem shrink to a certain extent. Modern tools 
used in work are often key factors in making decisions to settle in rural areas.

Nevertheless, it is important to bear in mind that despite favourable phenomena accompanying the revival of rural settlements, this process can also result in considerable landscape changes interfering with spatial harmony, or even leading to a change in the individual character of particular settlements;

\section{References}

Afrek A., 2015. Skutki krajobrazowe przerwania ciagłości osadnictwa. Prace Komisji Krajobrazu Kulturowego PTG, no. 28, pp. 47-64.

Baumann M., Kuemmerle T., Elbakidze M., Ozdogan M., Radeloff V.C., Keuler N.S., PrishChepov A.V., Kruhlov I., Hostert P., 2011. Patterns and drivers of post-socialist farmland abandonment in Western Ukraine. Land Use Policy, vol. 28, no. 3, pp. 552-562.

BORKOWSKI J., HRYNIEWICZZ., TOMASZEWSKI J., 1966. Granica rolno-leśna w Kotlinie Kamiennogórskiej. Zeszyty Problemowe Postępów Nauk Rolniczych, 12, Komitet Zagospodarowania Ziem Górskich PAN.

Bryś K., OJRzYŃSKA H., 2010. Przemiany krajobrazu wsi górskich w Sudetach Wschodnich [in:] Andrejczuk, W. (ed.), Krajobraz a turystyka, Prace Komisji Krajobrazu Kulturowego PTG, no. 14, pp. 157-173.

Chachau J., 1978. Problem wsi zanikajacej. Acta Universitatis Wratislaviensis, 324, Prace Instytutu Geograficznego, ser. B, 2, pp. 119-123.

Ciok S., 1991. Sudety. Obszar problemowy. Acta Universitatis Wratislaviensis, 1236, Studia Geograficzne, 51, Wrocław: Wydawnictwo Uniwersytetu Wrocławskiego.

Ciok S., 1994. Rozwój osadnictwa na Dolnym Ślasku po II wojnie światowej. Tendencje i kierunki zmian [in:] J. Łoboda (ed.), Przemiany ludnościowo-osadnicze i społeczno-gospodarcze na Dolnym Śląsku po II wojnie światowej, Acta Universitatis Wratislaviensis, 1591, Studia Geograficzne, 61, pp. 9-49.

Cıok S., 1995. Zmiany ludnościowe i osadnicze w Sudetach. Acta Universitatis Wratislaviensis, 1730, Prace Instytutu Geograficznego, ser. B, 12, an example of this could be Sienna, where the scale of investments connected with development of the Czarna Góra ski resort changed the character of the settlement.

\section{Editors' note:}

Unless oth erwise stated, the sources of tables and figures are the authors', on the basis of their own research.

Wrocław: Wydawnictwo Uniwersytetu Wrocławskiego pp. 51-64.

CZerWiński J., Marak J., WYrzYKoWski J., 2003. Możliwości rozwoju ekoturystyki w Polsce [in:] J. Wyrzykowski (ed.). Uwarunkowania rozwoju turystyki zagranicznej w Europie Środkowej i Wschodniej, Problemy rozwoju ekoturystyki ze szczególnym uwzględnieniem obszarów górskich. Wrocław: Wydawnictwo Uniwersytetu Wrocławskiego, pp. 79-92.

Drápela E., 2011. Geographical location of depopulation areas in the Czech Republic and its dependence on transport infrastructure: Part I: Definition, methodology, and quantitative analysis. Transactions on Transport Sciences, vol. 4, no. 1, pp. 31-40.

Eberhardt P., 1989. Regiony wyludniajace się w Polsce. Prace Geograficzne, 148, Warszawa: Instytut Geografii i Przestrzennego Zagospodarowania PAN.

GóreCKa S., Tomczak P., 2008. Demographic development of Lower Silesia with particular focus on the Polish-Czech and Polish-German borderland [in:] M. Sasek (ed.), Social and economic development and regional politics. Usti nad Labem: Jan Evangelista Purkyne University, pp. 50-61.

Jerkiewicz A., Krawiec K., Zagożdżon A., 1979. Zmiany ludnościowe $i$ osadnicze $w$ regionie kłodzkim. Zeszyty Problemowe Postępów Nauk Rolniczych, 223, Komitet Zagospodarowania Ziem Górskich PAN.

LATOCHA A., 2007. Przemiany środowiska przyrodniczego w Sudetach Wschodnich w warunkach antropopresji. Acta Universitatis Wratislaviensis, 3007, Studia Geograficzne, 80, Wrocław: Wydawnictwo Uniwersytetu Wrocławskiego. 
LATOCHA A., 2009. Land use changes and longerterm human-environment interactions in a mountain region (Sudetes Mountains, Poland). Geomorphology, vol. 108, no. 1, pp. 48-57.

LATOCHA A., 2010. Współczesne zmiany kulturowo-przyrodnicze obszarów pogranicza na przykładzie Sudetów [in:] S. Horska-Schwarz (ed.), Problemy zagospodarowania, ochrony i monitoringu krajobrazów strefy przygranicznej, Problemy Ekologii Krajobrazu, 26, pp. 181-194.

LATOCHA A., 2011. Contemporary landscape of depopulated areas as a mosaic of relict and active landscape features (Stołowe Mts case study). Problemy Ekologii Krajobrazu, 30, pp. 309-316.

LATOCHA A., 2012. Changes in the rural landscape of the Polish Sudety Mountains in the post-war period. Geographia Polonica, vol. 85, no. 4, pp. 13-21.

LATOCHA A., 2013. Wyludnione wsie w Sudetach. I co dalej?. Przegląd Geograficzny, vol. 85, no. 3, pp. 373-396.

MacDonald D., Crabtree J.R., Wiesinger G., Dax T., Stamou N., Fleury P., Gutierrez LazplTA J., GIBON A., 2000. Agricultural abandonment in mountain areas of Europe: Environmental consequences and policy response. Journal of Environmental Management, vol. 59, no. 1, pp. 47-69.

Mıgoń P., 1998. Ziemia Kłodzka: Przewodnik. Wrocław: Eko-Graf.

Miszewska B., 1979. Tendencje zmian ludnościowych $w$ Sudetach na przykładzie rejonu noworudzkiego. Czasopismo Geograficzne, vol. 50, no. 1-2, pp. 75-86.

MiszewSKA B., 1989. Zmiany zaludnienia Sudetów w okresie powojennym. Czasopismo Geograficzne, vol. 60, no. 2, pp. 135-145.

Mladenov Ch., Ilieva M., 2012. The depopulation of the Bulgarian villages. Bulletin of Geography. Socio-economic Series, 17, pp. 99-107.

NAMYŚLAK B., 2013. Działalności twórcze a rozwój miast: Przykład Wrocławia. Rozprawy Naukowe Instytutu Geografii i Rozwoju Regionalnego, 30. Wrocław: Uniwersytet Wrocławski.

Novotná M., Preis J., Kopp J., Bartoš M., 2013. Changes in migration to rural regions in the Czech Republic: Position and perspectives. Moravian Geographical Reports, vol. 21, no. 3, pp. 37-54.
Pijet-Migoń E., Migoń P., 2014. Turystyka w kreatywnej wsi - studium przypadku wsi Dobków na Pogórzu Kaczawskim. Rozprawy Naukowe Akademii Wychowania Fizycznego we Wrocławiu, 46, pp. 129-139.

Ротоскі J., 2000. Przemiany użytkowania terenu w Karkonoszach w ciagu ostatnich 100 lat (podtoże społeczno-ekonomiczne, środowiskowe konsekwencje. Opera Corcontica, 37, pp. 642-649.

Ротоскі J., 2009. Funkcje turystyki w kształtowaniu transgranicznego regionu górskiego Sudetów. Wrocław: Wrocławskie Towarzystwo Naukowe.

SALWICKA B., 1978. Zmiany w zaludnieniu i użytkowaniu ziemi wsi górskich Masywu Śnieżnika w strefie granicy rolno-leśnej. Acta Universitatis Wratislaviensis, 324, Prace Instytutu Geograficznego, ser. B, 2, Wrocław: Wydawnictwo Uniwersytetu Wrocławskiego, pp. 71-87.

SALWICKA B., 1983. Zmiany w zaludnieniu i użytkowaniu gruntów wsi górskich na wybranych obszarach przygranicznych Sudetów Kłodzkich. Acta Universitatis Wratislaviensis, 506, Studia Geograficzne, 32, Wrocław: Wydawnictwo Uniwersytetu Wrocławskiego, pp. 23-30.

ŚLESZYŃSKI P., 2005. Różnice liczby ludności ujawnione w Narodowym Spisie Powszechnym 2002. Przegląd Geograficzny, vol. 77, no. 2, pp. 193-212.

ŚlesZYŃSKI P., 2013. Prawidłowości zróżnicowań przestrzennych emigracji zagranicznej z Polski po 1989 r.. Studia Migracyjne - Przegląd Polonijny, vol. 39, no. 3, pp. 37-62.

SojA M., 2008. Cykle rozwoju ludności Karpat Polskich w XIX i XX wieku. Kraków: Instytut Geografii i Gospodarki Przestrzennej, Uniwersytet Jagielloński.

StRATEGIA ROZWOJU OBSZARÓW WIEJSKICH WOJEWÓDZTWA DOLNOŚLASKIEGO, 2000. Wrocław: Urząd Marszałkowski Województwa Dolnośląskiego.

SzMYTKIE R., 2008. Nieistniejace wsie w Sudetach [in:] M. Kulesza (ed.), Czas i przestrzeń w naukach geograficznych: Wybrane problemy geografii historycznej, Łódź: Uniwersytet Łódzki, pp. 225-242.

TOMASzEWSKI J., 1968. Zmiany ludnościowe w osiedlach sudeckich ze szczególnym uwzględnieniem powiatów Jelenia Góra i Bystrzyca Kłodzka. Problemy Zagospodarowania Ziem Górskich, 6, Komitet Zagospodarowania Ziem Górskich PAN.

WolsKI J., 2007. Przekształcenia krajobrazu wiejskiego Bieszczadów Wysokich w ciagu ostatnich 
150 lat. Prace Geograficzne, 214, Warszawa: Instytut Geografii i Przestrzennego Zagospodarowania PAN.

ZAGOŻDŻON A., 1983. Modele sieci osadniczej w rejonach górskich na tle współczesnych procesów przemian osadnictwa. Acta Universitatis
Wratislaviensis, 506, Studia Geograficzne, 32, Wrocław: Wydawnictwo Uniwersytetu Wrocławskiego, pp. 31-47.

ZAGOŻDŻON A., 1990. Wybrane problemy ludnościowe Sudetów na tle rozwoju regionalnego. Studia KPZK PAN, 96, pp. 95-111. 